\title{
Ubiquitinated or sumoylated retinoic acid receptor $\alpha$ determines its characteristic and interacting model with retinoid $X$ receptor $\alpha$ in gastric and breast cancer cells
}

\author{
Qiao Wu, Xiao-feng Lin, Xiao-feng Ye, Bing Zhang, Zhong Xie and Wen-jin Su \\ Key Laboratory of the Ministry of Education for Cell Biology and Tumor Cell Engineering, School of Life Sciences, Xiamen University, Xiamen 361005, \\ Fujian Province, China
}

(Requests for offprints should be addressed to Q Wu; Email: xgwu@xmu.edu.cn)

\begin{abstract}
Retinoic acid receptor $\alpha$ (RAR $\alpha$ ) plays an important role in mediating all-trans retinoic acid (ATRA) signals. In this study, we found that ATRA up-regulated RAR $\alpha$ mRNA and protein expression in gastric cancer BGC-823 cells. However, in breast cancer MCF-7 cells it down-regulated RAR $\alpha$ protein expression with no effect on its RAR $\alpha$ mRNA. Immunoprecipitation/Western blot analysis showed that, although sumoylated and ubiquitinated RAR $\alpha$ existed simultaneously in both cancer cell lines, ATRA exerted different regulatory effects on sumoylation and ubiquitination of RAR $\alpha$. In MCF-7 cells, ATRA treatment enhanced the ubiquitination of RAR $\alpha$ and the subsequent degradation of RAR $\alpha$ through the ubiquitin/proteasome pathway. This resulted in a reduction in the DNA binding activity of RAR $\alpha /$ retinoid $X$ receptor $\alpha(R X R \alpha)$ heterodimer, the separation of $R X R \alpha$ from RAR $\alpha$ and the translocation of $R X R \alpha$ from the nucleus to the cytoplasm. By contrast, in BGC-823 cells, ATRA augmented sumoylation, not ubiquitination, of RAR $\alpha$. The stability of sumoylated RAR $\alpha$ was significantly stronger than in non-sumoylated RAR $\alpha$. These results also showed an increase in the DNA binding activity of the $\mathrm{RAR} \alpha / \mathrm{RXR} \alpha$ heterodimer and the stability of nuclear localization of this heterodimer, which normally facilitates the ATRA signal transduction. In conclusion, our results reveal a novel mechanism for the regulation of RAR $\alpha$-dependent signal transduction through the ubiquitin/proteasome pathway in breast cancer cells and the sumoylation pathway in gastric cancer cells.
\end{abstract}

Journal of Molecular Endocrinology (2004) 32, 595-613

\section{Introduction}

Retinoic acid (RA) and its natural and synthetic vitamin A derivatives, retinoids, are known as regulators of a broad range of biological processes and are used in the treatment of epithelial cancer and promyelocytic leukemia (Gudas et al. 1994, Hong \& Itri 1994). The physiological function of RA is mediated through its cellular receptors, the retinoic acid receptors $(\operatorname{RAR} \alpha, \beta$, and $\gamma)$ and the retinoid X receptors $(\mathrm{RXR} \alpha, \beta$, and $\gamma$ ) (Zhang \& Pfahl 1993, Kastner et al. 1995). RARs and RXRs are commonly located in the nucleus and thus are classified as nuclear receptors. RXRs usually form homodimers, RXR/RXR, or interact with RARs to form heterodimers, RAR/RXR (Kliewer et al.
1992, Leid et al. 1992, Marks et al. 1992). RA can pass through the cell membrane and enter the nucleus via free diffusion, thus interacting with and binding to its nuclear receptors $\mathrm{RAR} / \mathrm{RXR}$ or $\mathrm{RXR} / \mathrm{RXR}$. These dimers can bind to and act on RA response elements (RAREs) to control the expression of relevant RA-responsive genes in the presence of RA ( $\mathrm{Yu}$ et al. 1991, Bugge et al. 1992, Kliewer et al. 1992, Leid et al. 1992, Zhang et al. 1992). The transcriptional activity of retinoid receptors is mainly controlled by ligand binding; however posttranscriptional covalent modifications, such as phosphorylation, ubiquitination and sumoylation, also play an important role in regulation of retinoid receptor activity (Sternsdorf et al. 1999b, Lallemand-Breitenbach et al. 2001, Tanaka et al. 
2001, Gianni et al. 2002). These posttranslational modifications often elicit fast alterations in the protein-protein interactions of multiprotein complexes and subcellular structures.

Some nuclear receptors are known to be degraded by covalent ligation to ubiquitin, a highly conserved 76-amino acid peptide, via the lysine residues (Li et al. 1999, Nawaz et al. 1999, Gianni et al. 2002). Protein ubiquitination is initiated by multiple enzyme reactions catalyzed by ubiquitinactivating enzyme (E1), ubiquitin-conjugating enzymes (E2s), and ubiquitin-protein ligases (E3s) (Weissman 1997, Wilkinson 2000). Evidence has been found that the fate of the ubiquitinated protein is determined by the types of ubiquitin conjugate formed. For instance, a single ubiquitin tag does not target a protein for proteasomal degradation, whereas a chain of four or more does (Thrower et al. 2000). Therefore, the polyubiquitin chain is essential for the degradation of proteins whose levels are regulated either constitutively or in response to changes in the cellular environment (Tanaka et al. 2001). In addition, ubiquitinated proteins are recognized specifically by a large protease complex, known as the 26S proteasome (Fenteany et al. 1995, Hochstrasser 1996), which may be responsible for $80-90 \%$ of protein degradation in the cell (Lee \& Goldberg 1998). It is now understood that both ubiquitin and the proteasome can also carry out various nonproteolytic tasks, controlling activities as diverse as receptor internalization (Terrell et al. 1998), ribosome function (Spence et al. 2000) and nucleotide excision repair (Russell et al. 1999).

The small ubiquitin-related modifier (SUMO) modification pathway (sumoylation) resembles that of ubiquitin conjugation, however the enzymes involved in the two processes are distinct (Melchior 2000). SUMO-1, also named Sentrin, Ubll or, in yeast, Smt3 (Johnson et al. 1997, Kamitani et al. 1997), is 18\% identical to ubiquitin and utilizes a similar conjugation pathway. This pathway involves activation by a heterodimeric Aos1-Uba2 activating enzyme (E1) and conjugation to a substrate by Ubc9 (Johnson et al. 1997, Johnson \& Blobel 1999), a protein with a strong sequence similarity to ubiquitin-conjugating enzymes (E2s). However, unlike ubiquitin, SUMO-1 does not conjugate to itself and thus is not capable of forming chains similar to polyubiquitin. Recently, the functions of SUMO-1 modification have been promulgated by accumulated reports. It appears to play multiple roles including protein targeting, protein stabilization and transcriptional activation. SUMO-1 conjugation has been found to alter the subcellular localization of its RanGAP1, Sp100 and PML substrates (Mahajan et al. 1997, Duprez et al. 1999, Sternsdorf et al. 1999a). Sumoylation of p53 is believed to increase its transcriptional activity (Gostissa et al. 1999, Rodriguez et al. 1999). However, SUMO-1 has an entirely different effect on $\mathrm{I} \kappa \mathrm{B} \alpha$, where it attaches to the major ubiquitination site preventing ubiquitination and protecting sumoylated I $\mathrm{I} \mathrm{B} \alpha$ from proteasomedependent proteolysis (Desterro et al. 1998).

Our previous studies have demonstrated that the expression and localization of $\operatorname{RAR} \alpha$ and $\operatorname{RXR} \alpha$ are associated with diverse signaling transduction pathways and their resulting physiological processes in carcinoma cells (Wu et al. 2002b, Ye et al. 2004). In addition, we have found that $\operatorname{RAR} \alpha$ may regulate the signaling switch from RAR-mediated to RXR-mediated growth inhibition in breast cancer cells $(\mathrm{Wu}$ et al. 1997a), however, the regulatory role of retinoic acid on $\operatorname{RAR} \alpha$ at the posttranscriptional level is still largely unknown. In this study, we have investigated RAR $\alpha$ ubiquitination and sumoylation in breast and gastric cancer cell lines and further inquired into the regulatory effect of all-trans retinoic acid (ATRA) on RAR $\alpha$ ubiquitination and sumoylation, as well as the resultant functional influences in these cells.

\section{Materials and methods}

\section{Cell culture}

Cell lines, including MCF-7 (breast cancer) and BGC-823 (gastric cancer) were obtained from the Institute of Cell Biology, Shanghai, China. The MGC80-3 cell line was established by the Cancer Center in Xiamen University, Fujian, China. Cells were maintained in RPMI-1640 medium supplemented with $10 \%$ fetal bovine serum, $1 \mathrm{mmol} / \mathrm{l}$ glutamine and $100 \mathrm{U} / \mathrm{ml}$ penicillin, and cultured in a humidified atmosphere supplemented with $5 \%$ $\mathrm{CO}_{2}$ at $37^{\circ} \mathrm{C}$.

\section{Antibodies and inhibitors}

Monoclonal antibodies against SUMO-1 and ubiquitin were purchased from Zymed Laboratories 
(San Francisco, CA, USA) and Santa Cruz Biotechnology (Santa Cruz, CA, USA) respectively. Polyclonal antibodies against RAR $\alpha$ and $\operatorname{RXR} \alpha$ were obtained from Santa Cruz. The proteasome inhibitors, ALLN (N-acetyl-Leu-Leu-Norleu-al), MG132 $(\mathcal{N}$-Cbz-Leu-Leu-Leu-al), and ALLM ( $\mathcal{N}$-acetyl-LeuLeu-Met-al), were purchased from Sigma.

\section{Northern blotting}

Total RNA was isolated by guanidium thiocyanate followed by ultracentrifugation in $\mathrm{CsCl}$ solutions as described previously (Wu et al. 2002a). Twenty micrograms total RNA were denatured with formaldehyde, fractionated by electrophoresis on $1 \%$ agarose-formaldehyde gel, and blotted onto nitrocellulose membrane. RAR $\alpha$ cDNA was labeled with $\left[\alpha-{ }^{32} \mathrm{P}\right] \mathrm{dATP}$ and $\left[\alpha-{ }^{32} \mathrm{P}\right] \mathrm{dCTP}$, using the random primer method. The membrane was prehybridized at $42{ }^{\circ} \mathrm{C}$ for $4 \mathrm{~h}$ and then hybridized with radiolabeled $\mathrm{RAR} \alpha$ cDNA overnight at $42{ }^{\circ} \mathrm{C}$. After hybridization, the nylon filter was washed twice with $2 \times \mathrm{SSC}$ and $0 \cdot 1 \% \mathrm{SDS}$ at $42{ }^{\circ} \mathrm{C}$ and finally washed twice with $1 \times \mathrm{SSC}$ and $0 \cdot 1 \%$ SDS at $60^{\circ} \mathrm{C}$. mRNA was visualized in X-ray film at $-80{ }^{\circ} \mathrm{C}$ overnight. $18 \mathrm{~S}$ and $28 \mathrm{~S}$ RNA indicated the amount of total RNA used in each lane. RAR $\alpha$ mRNA level was quantified by Densitometer. Data were means \pm s.D. for duplicate experiments.

\section{Western blotting}

Cell extract was essentially prepared according to the method previously described (Wu et al. 2002c). In brief, lysate was boiled for $5 \mathrm{~min}$ and centrifuged at $30000 \boldsymbol{g}$ for $10 \mathrm{~min}$ to remove cellular debris. Protein concentration was determined by the bicinchoninic acid method (Pierce Science). Fifty micrograms total protein were loaded onto an 8-10\% denaturing gel and then transferred to a nitrocellulose membrane. The membrane was incubated with appropriate antibody overnight, followed by the corresponding secondary antibody for 3-4 h. Protein was visualized on X-ray film by enhanced chemiluminescence (EGL, Pierce Biotechnology, IL, USA) according to the manufacturer's instructions. $\alpha$-Tubulin indicated the amount of protein used in each lane. RAR $\alpha$ protein level was quantified by Densitometer. Data were means \pm s.E. for three independent experiments.

\section{Transient transfection assay}

The reporter $\beta$ RARE ( $\beta$ retinoic acid response element) was linked with a thymidine kinase promoter ( $\beta$ RARE-tk-CAT) (Hoffmann et al. 1990). The RAR $\alpha$ expression vector used has been described elsewhere (Wu et al. 1997a,b). In order to measure the transcriptional activity of $\beta$ RARE, the reporter, together with $\mathrm{RAR} \alpha$ and $\beta$-galactosidase expression vector (pCH110, Pharmacia), were transiently transfected into cells by the calcium phosphate precipitation method. After transfection, cells were treated with $10^{-6} \mathrm{~mol} / \mathrm{l}$ ATRA for $24 \mathrm{~h}$, and then harvested and lysed. The extract was assayed for $\beta$-galactosidase and CAT activity. All CAT activity was normalized by $\beta$-galactosidase activity. The data shown are the means of three separate experiments.

\section{Immunoprecipitation/Western blot analysis}

Cells were washed three times with ice-cold PBS and lysed in $1 \mathrm{ml}$ ELB buffer $(140 \mathrm{mM} \mathrm{NaCl}, 0 \cdot 5 \%$ NP40, $100 \mathrm{mM}$ NaF, $50 \mathrm{mM}$ Tris/HCl pH 8.0), then vortexed and centrifuged at $15000 \boldsymbol{g}$ for 10 min to obtain all cell lysate (supernatant). To preclear the cell lysate, it was mixed and incubated with protein A beads for $30 \mathrm{~min}$ and centrifuged for $15 \mathrm{~min}$ at $1000 \boldsymbol{g}$ to get preclear lysate (supernatant). The precleared lysate was then incubated with anti-RAR $\alpha$ antibody for $2 \mathrm{~h}$. The resulting antigen-antibody complexes were bound to protein A-Sepharose and incubated for an additional $4 \mathrm{~h}$ at $4{ }^{\circ} \mathrm{C}$. After a brief centrifugation at $1000 \mathrm{~g}$, the immunoprecipitate was collected and divided into two parts. One was subjected to Western blot analysis with corresponding antibodies, such as ubiquitin, SUMO-1 or RXR $\alpha$, to indicate their interaction with $\operatorname{RAR} \alpha$. The other was analyzed by Western blotting with the anti-RAR $\alpha$ antibody to indicate the amount of immunoprecipitated RAR $\alpha$ protein used in each lane. About $50 \sim 100 \mu \mathrm{g}$ nuclear extract were applied to ascertain the position of blotted proteins (Input).

\section{Nuclear extract preparation and gel retardation assay}

The nuclear extract was essentially prepared according to the method described previously $(\mathrm{Wu}$ et al. 1997b). In brief, cells were grown to about 
90\% confluence, washed with cold PBS and scraped into PBS using a rubber policeman. Cells were pelleted by low-speed centrifugation, then resuspended in a buffer containing $10 \mathrm{mM}$ Tris-HCl (pH 7.4), $3 \mathrm{mM} \mathrm{CaCl}_{2}$, and $2 \mathrm{mM}$ $\mathrm{MgCl}_{2}$, then re-pelleted and lysed in buffer containing $1 \%$ Nonidet $\mathrm{p}-40$ by 20 strokes using an ice-cold Dounce homogenizer. Immediately after lysis, nuclei were collected by centrifugation at $2000 \mathrm{~g}$ and washed once in a buffer containing $10 \mathrm{mM}$ HEPES-KOH (pH 7.9), $1.5 \mathrm{mM} \mathrm{MgCl}_{2}$, $10 \mathrm{mM} \mathrm{KCl}$, and $0.5 \mathrm{mM}$ dithiothreitol. Nuclear protein was extracted with a high-salt buffer containing $20 \mathrm{mM}$ HEPES-KOH (pH 7.9), 25\% glycerol, $420 \mathrm{mM} \mathrm{NaCl}, 1.5 \mathrm{mM} \mathrm{MgCl}_{2}, 0.2 \mathrm{mM}$ EDTA and $0.5 \mathrm{mM}$ dithiothreitol. Protein concentration was determined by the bicinchoninic acid method (Pierce Science). The supernatants were stored at $-70{ }^{\circ} \mathrm{C}$. All the buffers used for the procedure contained protease inhibitors, such as PMSF $(100 \mu \mathrm{g} / \mathrm{ml})$, leupeptin $(1 \mu \mathrm{g} / \mathrm{ml})$ and aprotinin $(1 \mu \mathrm{g} / \mathrm{ml})$. The ${ }^{32}$ P-labeled receptor response element DR5 (oligonucleotide: 5'-TGGAGGG TAGGGTTCACGGAAAGTTCACTCG-3') was used as a probe, as described in the published literature (Tanaka et al. 2001). Five micrograms nuclear extract were incubated first with $1 \mu \mathrm{l}$ of required antibody at room temperature for $30 \mathrm{~min}$, then with the probe at room temperature for another $30 \mathrm{~min}$ prior to gel retardation assay. The gel retardation assay was completed on a nondenaturing polyacrylamide gel at $4{ }^{\circ} \mathrm{C}$, which was then dried under vacuum and exposed at $-80{ }^{\circ} \mathrm{C}$ overnight.

\section{Laser-scanning confocal microscopy}

Cells were immunostained according to the method described previously by $\mathrm{Wu}$ et al. (2002b). Briefly, cells were cultured on covered glass overnight and then treated with ATRA or other agents as required. After washing with phosphate-buffered saline (PBS), cells were fixed in 4\% paraformaldehyde. To display the RAR $\alpha$ or RXR $\alpha$ proteins, cells were incubated with anti-RAR $\alpha$ or anti$\mathrm{RXR} \alpha$ antibody respectively, then reacted with the corresponding secondary antibody - Texas-redconjugated (Molecular Probes, Eugene, OR, USA) or FITC-conjugated anti-IgG (BD Biosciences, Pharmingen, San Diego, CA, USA). Fluorescent images were examined and analyzed under a laser-scanning confocal microscope (Bio-Rad MRC-1024ES).

\section{Pulse-chase experiment}

This experiment was completed as described by Osburn (Osburn et al. 2001). Cells were labeled with ${ }^{35} \mathrm{~S}$-methionine $(0 \cdot 1 \mathrm{mCi} / \mathrm{ml})$ in methioninefree DMEM medium for $4 \mathrm{~h}$. After labeling, cells were either directly lysed or chased with the addition of $2 \mathrm{mM}$ cold methionine for the indicated time points in the absence or presence of ATRA. Upon completion of chase, cells were washed with ice-cold PBS three times and collected. Cells were pelleted for $1 \mathrm{~min}$ at $14000 \mathrm{~g}$ at $4{ }^{\circ} \mathrm{C}$, and then lysed in $200 \mu$ lysis buffer $(50 \mathrm{mM}$ Tris $(\mathrm{pH} 8 \cdot 8)$, $5 \mathrm{mM}$ EDTA, 2\% SDS, $10 \mathrm{mM}$ dithiothreitol, $100 \mu \mathrm{M}$ sodium vanadate, $10 \mathrm{mM}$ sodium fluoride, protease inhibitors). The supernatant was precleared through incubation with protein A/Gagarose for $30 \mathrm{~min}$ and then centrifuged to obtain the pre-cleared supernatant. The pre-cleared supernatant was incubated with anti-RAR $\alpha$ antibody for $1 \mathrm{~h}$ and the resulting antigen-antibody complexes were bound to protein A-Sepharose and further incubated for an additional $4 \mathrm{~h}$ at $4{ }^{\circ} \mathrm{C}$. After a brief centrifugation at $1000 \mathrm{~g}$, the immunoprecipitate was collected and washed three times with lysis buffer, separated on $8 \%$ SDS-PAGE. Finally, the gel was dried under vacuum and exposed at $-80^{\circ} \mathrm{C}$ for 7 days. Protein levels were quantified by Densitometer. The bars represent \pm S.D from three independent assays.

\section{Results}

\section{ATRA induced distinct patterns of alteration on transcriptional activity and protein synthesis of RAR $\alpha$ in different cell lines}

Northern blot and Western blot showed that in gastric cancer cells BGC-823, ATRA could enhance RAR $\alpha$ expression in both mRNA and protein levels in a time-dependent manner (Fig. 1A). The results also showed an enhancement of RAR $\alpha$ mRNA ( $\sim$ fourfold) and protein $(\sim$ threefold). This was clearly observed after $24 \mathrm{~h}$ of ATRA addition, as compared with the control (Fig. 1B). By contrast, in the breast cancer cells MCF-7, there was not an obvious change in RAR $\alpha$ mRNA expression (Fig. 1A) and the cell's protein level was 
A.
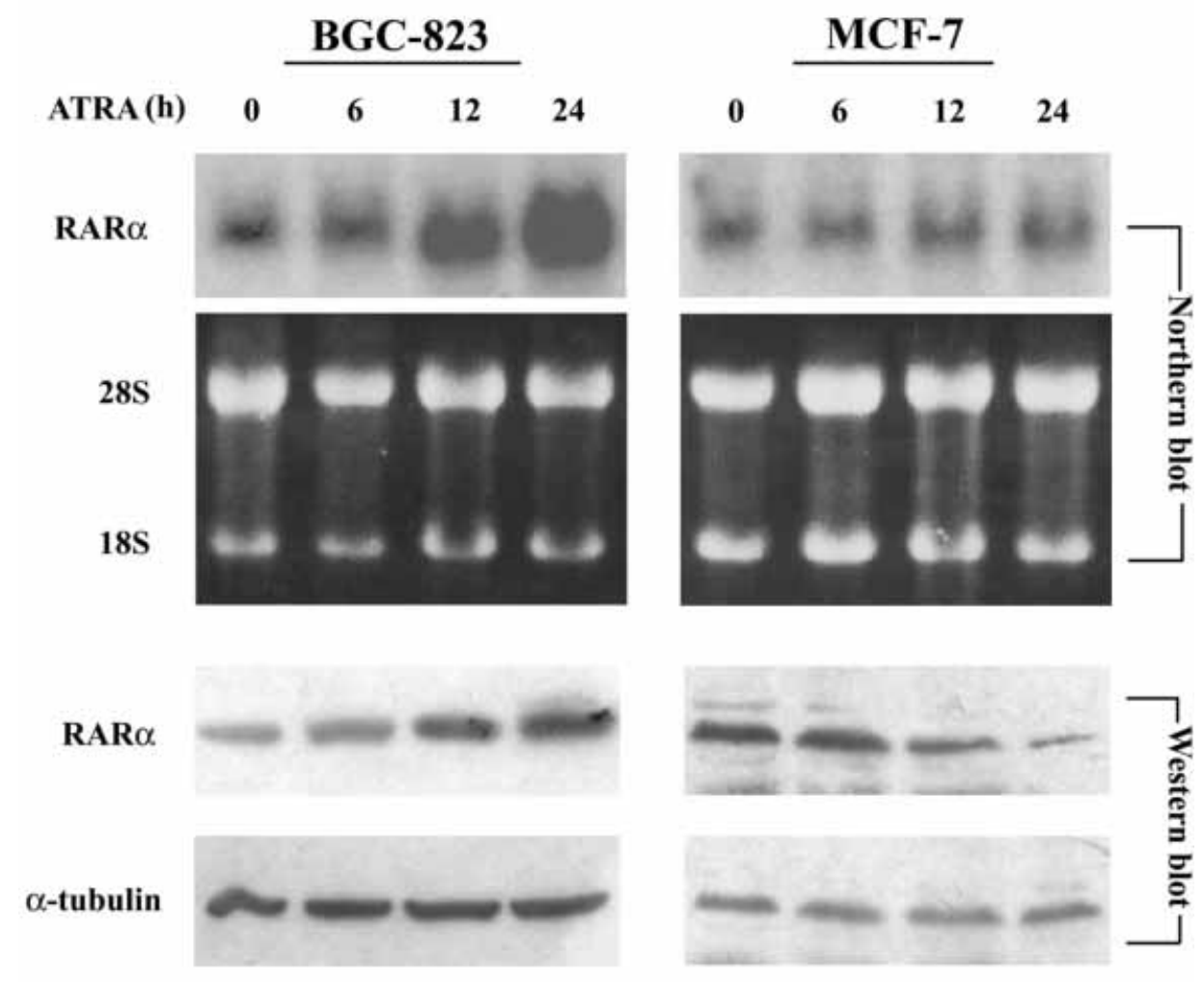

B.
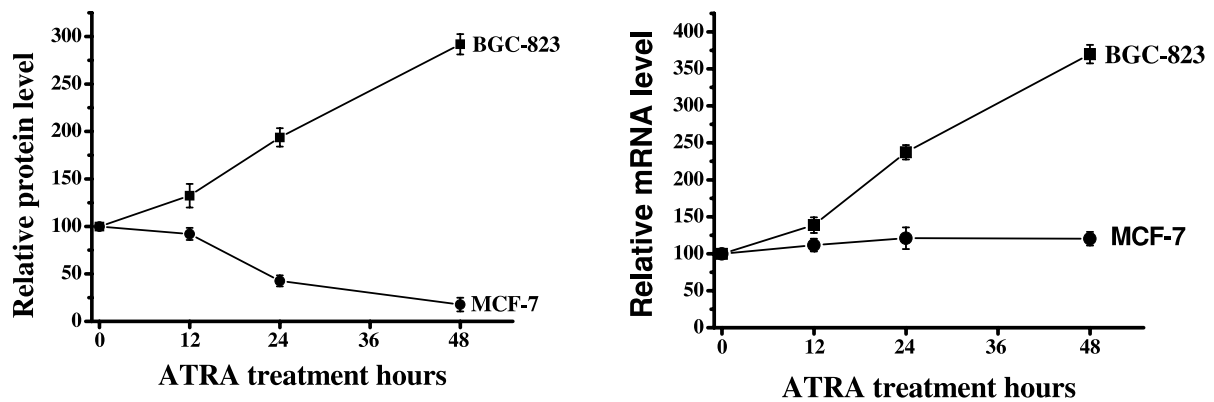

Figure $1(A)$ and $(B)$.

significantly inhibited (more than $80 \%$ inhibition as compared with the control) at $24 \mathrm{~h}$ of treatment with ATRA (Fig. $1 \mathrm{~A}$ and B). However, the expression of RXR $\alpha$ was not affected by ATRA treatment either at the mRNA or protein level in both gastric and breast cancer cell lines (data not shown). The distinct patterns of ATRA-treated
RAR $\alpha$ mRNA and protein expression in these two cell lines suggest that RAR $\alpha$ may have a functional role in mediating ATRA signaling events in different cell lines.

The interactions between ATRA and its receptors, as well as the resultant functional effect on the transcriptional activity of the reporter, were 
C.

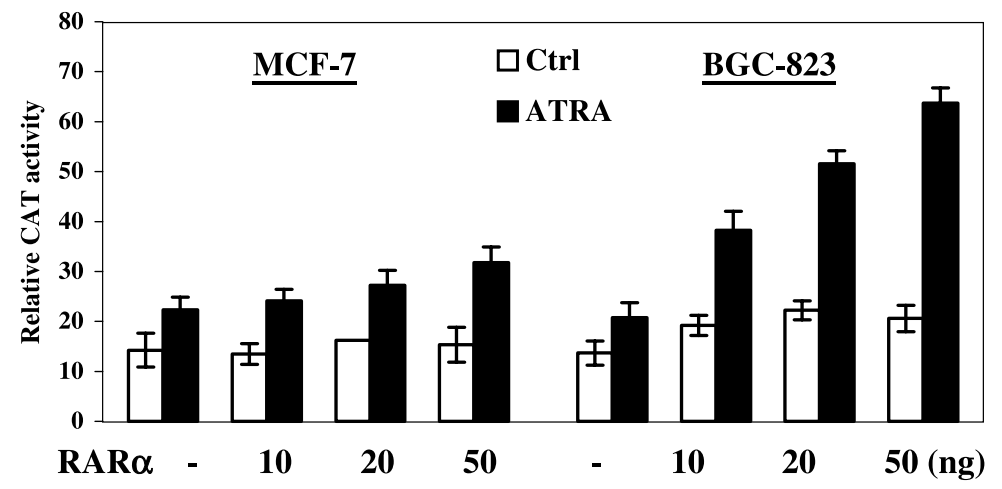

D.
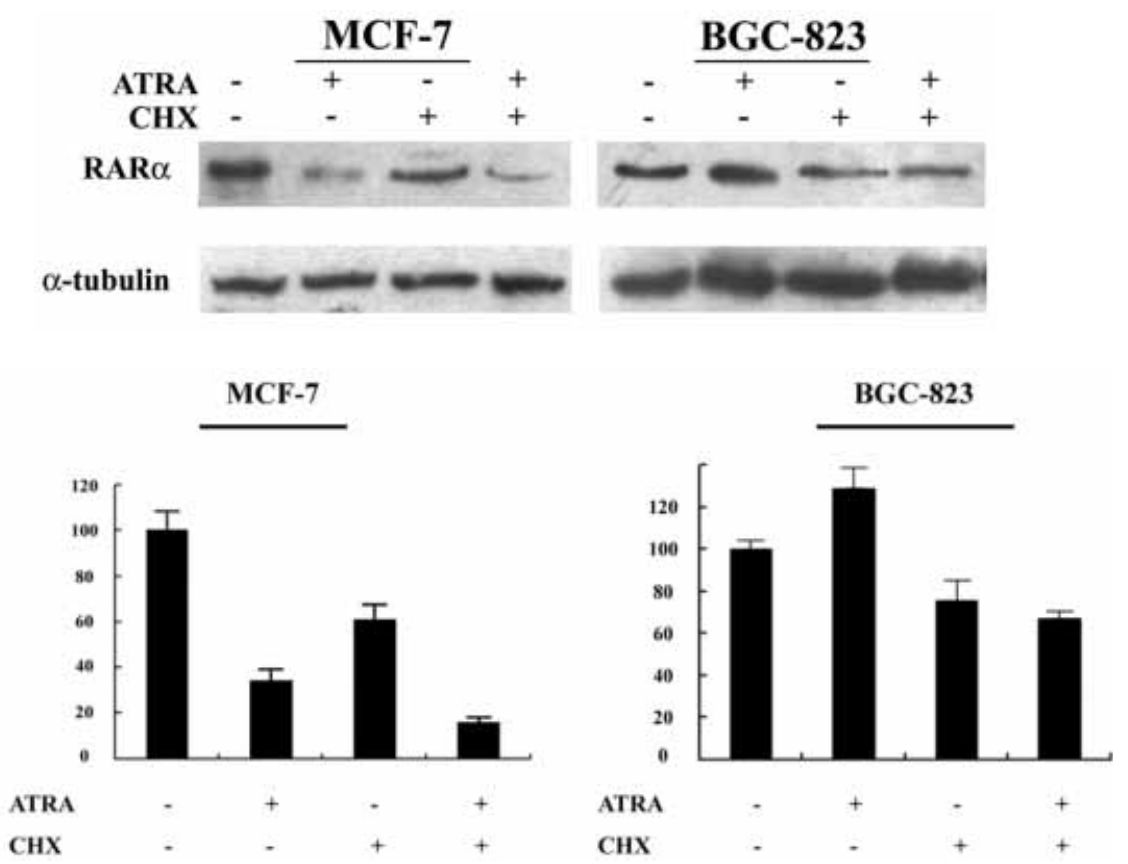

Figure $1(C)$ and (D).

further tested by transient transfection assay in both cancer cell lines. Here, a CAT reporter containing $\beta R A R E$ (RA response element) linked with a thymidine kinase promoter ( $\beta$ RARE-tk-CAT) was used. When transfected into both MCF-7 and BGG-823 cells respectively, CAT activity in response to ATRA was observed due to endogenous RAR $\alpha$ and RXR $\alpha$ activity (Fig. 1G). More importantly, the ATRA-induced CAT activity in BGC-823 cells cotransfected with both reporter and RAR $\alpha$ expression vector, was affected by $\mathrm{RAR} \alpha$ in a concentration-dependent manner and 
was higher than in MCF-7 cells (Fig. 1G). This difference implied that ATRA induction might initiate the distinct behavior of the RA target gene transcription in these two cell lines.

Low RAR $\alpha$ protein levels in ATRA-treated MCF-7 cells may be due to the reduced rate of $\operatorname{RAR} \alpha$ protein synthesis and/or the accelerated rate of its degradation. To explore this question, cycloheximide (CHX) was used to prevent new protein synthesis in Western blot examination. As shown in Fig. 1D, in MCF-7 cells, the RAR $\alpha$ protein level in the CHX-treated sample was lower than that of control, indicating the inhibitory effect of CHX on RAR $\alpha$ protein synthesis, yet it was higher than the ATRA-treated sample. In addition, in cells treated with CHX plus ATRA, the RAR $\alpha$ protein level was significantly lower than after either ATRA or CHX treatment alone (Fig. 1D), indicating that ATRA-related low RAR $\alpha$ protein in MCF-7 cells was likely to be due to the accelerated rate of RAR $\alpha$ breakdown.

A parallel experiment was carried out in BGC-823 cells and as shown in Fig. 1D, CHX not only inhibited the newly synthetic process of RAR $\alpha$ protein, but also abolished the high $\operatorname{RAR} \alpha$ protein level stimulated by ATRA alone (Fig. 1A and D). This indicates that the portion of $\operatorname{RAR} \alpha$ augmented by ATRA was produced by accelerating the rate of its protein synthesis.

\section{ATRA exerts diverse effects on RARa ubiquitination and sumoylation in different cell lines}

An interesting phenomenon appeared when the RAR $\alpha$ protein from both MCF-7 and BGC-823 cells was examined by Western blot analysis. Many reacting bands (between 63.8 and $113.7 \mathrm{kDa}$ ) were observed in both cell lines (Fig. 2A, modified), suggesting that other molecules, such as SUMO-1 or ubiquitin, may be covalently conjugated to $\operatorname{RAR} \alpha$, resulting in the up-shift of $\operatorname{RAR} \alpha$ onto bands of higher molecular weight. We further analyzed the status of RAR $\alpha$, testing the possibility of its ubiquitination and sumoylation. RAR $\alpha$ was immunoprecipitated with an anti-RAR $\alpha$ antibody on extracts from both gastric and breast cancer cell lines and these immunoprecipitates were subjected to Western blotting with anti-ubiquitin antibody. As indicated by the molecular marker, only protein of upper-bands could be detected by the antiubiquitin antibody in both BGC-823 and MCF-7 cells, implying that the RAR $\alpha$ may be in some ubiquitinated form in both cell lines (Fig. 2B). With the extension of ATRA treatment, further accumulation of ubiquitinated-RAR $\alpha$ could be seen in the MCF-7 cells even as early as $12 \mathrm{~h}$ treatment, but not in BGC-823 cells (Fig. 2B). The molecular weight of ubiquitin has been reported to be about $8.5 \mathrm{kDa}$ (Goldstein et al. 1975), but the bands of interest have a molecular mass within the range of $40 \sim 50 \mathrm{kDa}$ (Fig. 2A and B), suggesting that four or more ubiquitin molecules might covalently conjugate with $\operatorname{RAR} \alpha$.

A parallel experiment was conducted on anti-RAR $\alpha$ immunoprecipitates from the extracts of these two cell lines. The immune complexes were probed with anti-SUMO-1, instead of anti-ubiquitin antibody. The results showed that the RAR $\alpha$-SUMO-1 complex appeared in samples from both MCF-7 and BGC-823 cells and that the intensity increased from $12 \mathrm{~h}$ of ATRA treatment. The time-dependent augmented action of the RAR $\alpha-S U M O-1$ complex by sustained ATRA treatment only occurred in the BGC-823 cells, not in MCF-7 cells (Fig. 2C). Therefore, the patterns of $\operatorname{RAR} \alpha$ ubiquitination and sumoylation stimulated by ATRA were significantly divergent

Figure 1 Expression of RAR $\alpha$ mRNA and protein in response to ATRA. (A) Time-dependent effect of ATRA on expression level of RAR $\alpha$ mRNA and protein. Cells were treated with ATRA $\left(10^{-6} \mathrm{~mol} / \mathrm{l}\right)$ for different times as indicated. RAR $\alpha$ mRNA and protein were examined by Northern blot and Western blot respectively. 28S and $18 \mathrm{~S}$ indicates the amount of total RNA used and $\alpha$-tubulin indicates the amount of protein used in each lane.

(B) Densitometric analysis of RAR $\alpha$ mRNA and protein. The data represented the means of duplicate experimental results for mRNA and protein respectively. (C) Transactivational activity of the $\beta R A R E$ in MCF-7 and BGC-823 cells. Cells were transfected only with $\beta$ RARE-tk-CAT reporter plasmid or together with RAR $\alpha$ expression vector as indicated. Transfected cells, ATRA treated or not treated, were assayed after 24-h incubation. Data represent the means of three independent experiments. (D) Effect of cycloheximide (CHX) on RAR $\alpha$ protein synthesis in the absence or presence of ATRA. Cells were pre-treated with $\mathrm{CHX}(10 \mathrm{mg} / \mathrm{ml})$ for $3 \mathrm{~h}$ followed by ATRA for another $12 \mathrm{~h}$. Expression of RAR $\alpha$ protein was examined by Western blot and quantified by Densitometer. Results are mean \pm S.D. in B, C and D. 
A.

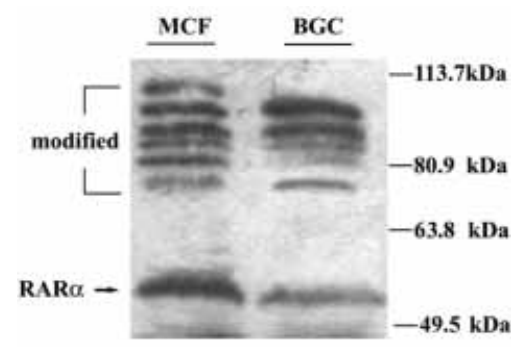

B.

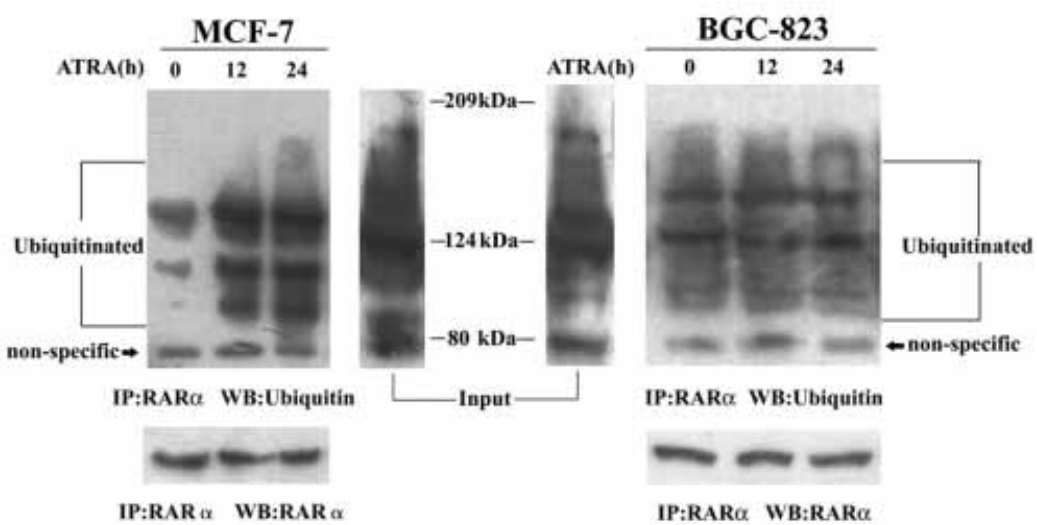

C.

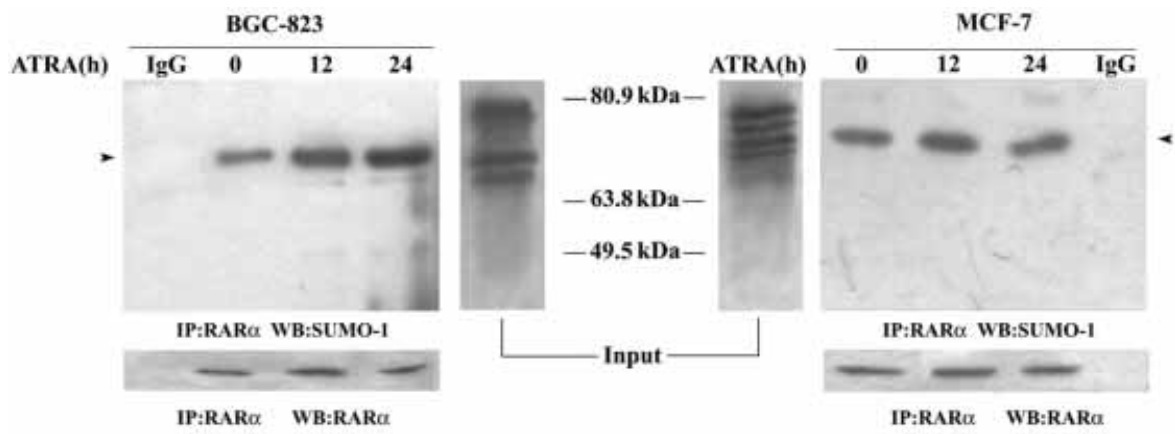

Figure 2 Ubiquitination and sumoylation of RAR $\alpha$ in response to ATRA in different cell lines. (A) Protein expression of RAR $\alpha$ was examined by Western blot. The lowest band is endogenous RAR $\alpha$, and the upper bands are these modified. (B) Whole cell extracts were immunoprecipitated with anti-RAR $\alpha$ antibody, then divided into two parts. After the regular SDS-PAGE and blotting procedures, samples were probed with anti-ubiquitin antibody for demonstrating the formation of RAR $\alpha$-ubiquitin complex, or probed with anti-RAR $\alpha$ antibody for quantifying the amount of immunoprecipitated RAR $\alpha$ protein used in each lane respectively. The same nuclear extract was applied to ascertain the position of protein by Western blotting (Input). (C) The sample was prepared as described in (B), but probed with anti-SUMO-1 antibody. IgG was used as a negative control, no band appeared in the position corresponding to SUMO-1. IP, Immunoprecipitation; WB, Western Blotting. 
in the different cells (Fig. 2B and G). In summary, Fig. 2 demonstrates that although both ubiquitination and sumoylation of the $\operatorname{RAR} \alpha$ protein are normal events in gastric and breast cancer cells, ATRA is able to enhance RAR $\alpha$ ubiquitination in MCF-7 cells and RAR $\alpha$ sumoylation in BGC-823 cells. This effect may relate to the divergent biological roles of $\operatorname{RAR} \alpha$ in different cell types.

\section{Ubiquitin/proteasome pathway mediates RAR $\alpha$ degradation}

Based on the results shown in Fig. 2B, it might be suggested that degradation of RAR $\alpha$ is associated with the ubiquitination pathway in MCF-7 cells. Since, as in most cases, ubiquitination is closely associated with the protein degradation-related proteasome, the possible involvement of the ubiquitin/proteasome pathway was evaluated by using compounds known to inhibit proteasome activity. In this experiment, proteasome-specific inhibitors, MG132 (potent cell permeable proteasome inhibitor), ALLN (inhibitor for calpains, cathepsins and proteasomal proteolysis), and ALLM (a potential inhibitor for calpains and cathepsins, but not for proteasome) were used (Rock et al. 1994). As shown in Fig. 3A, the addition of MG132 and ALLN completely blocked ATRAinduced degradation of RAR $\alpha$ in MCF-7 cells, while ALLM was much less effective. These results indicated that not only the proteasome, but also the ubiquitination pathway might be involved in degradation of RAR $\alpha$ by ATRA. We further analyzed the relationship between ubiquitination/ proteasome and degradation of RAR $\alpha$ using these inhibitors in an immunoprecipitation/Western blot experiment on MCF-7 cells. ALLN increased the intensity of the ubiquitin-containing complex when compared with the control. Treatment with ATRA together with ALLN caused a marked increase in accumulation, not degradation, of the ubiquitinated complex. This complex was even more abundant than that of the ALLN treatment alone (Fig. 3B). The enhancing effect was also found in the MG132 treatment group (data not shown), but not in the ALLM treatment group (Fig. 3B). Clearly, ALLN and MG132, rather than ALLM, block the ATRA-induced $\operatorname{RAR} \alpha$ degradation pathway and promote the accumulation of ubiquitinated RAR $\alpha$. This indicates the existence of a close correlation between the ubiquitination/ proteasome pathway and $\operatorname{RAR} \alpha$ degradation.

\section{RAR $\alpha$ ubiquitination/degradation decreases its heterodimerization with $\mathrm{RXR \alpha}$}

Next, we investigated whether the ubiquitination and sumoylation of $\operatorname{RAR} \alpha$ may affect RAR $\alpha-$ $\mathrm{RXR} \alpha$ heterodimer interaction. The cellular localization of RAR $\alpha$ and RXR $\alpha$ in MGC-823 and MCF-7 cells with and without ATRA treatment was first examined. $\operatorname{RAR} \alpha$ and $\operatorname{RXR} \alpha$ proteins were immunostained using relevant antibodies and fluorescent secondary antibodies, and then examined under a laser scanning confocal microscope. The result demonstrated that $\operatorname{RAR} \alpha$ and $\mathrm{RXR} \alpha$ occupy the same nuclear location in both MCF-7 and BGC-823 cells, shown by a unique yellow color due to the overlapping of red RAR $\alpha$ with green $\operatorname{RXR} \alpha$ (Fig. 4A). In response to ATRA treatment, most of the $\mathrm{RXR} \alpha$ protein showed a clear translocation from the nucleus to the cytoplasm in MCF-7 cells (Fig. 4A). In contrast, RXR $\alpha$ remained in the nucleus of BGC-823 cells, even after $24 \mathrm{~h}$ of ATRA treatment (Fig. 4A). Results from the experiments on RAR $\alpha$ showed it remained in the nucleus and there was no ATRA-induced translocation found in either BGC-823 or MCF-7 cells (Fig. 4A). These results infer an association of RAR $\alpha$ with $\mathrm{RXR} \alpha$ in BGC-823 cells and a disassociation accompanied by $\mathrm{RXR} \alpha$ nucleocytoplasmic translocation in MCF-7 cells in response to ATRA.

The heterodimerization status of $\operatorname{RAR} \alpha$ with $\operatorname{RXR} \alpha$ was then analyzed by gel retardation assay and further confirmed by immunoprecipitation/ Western blot. Nuclear proteins were prepared from both MCF-7 and BGC-823 cells for gel retardation assay. When receptor response element DR-5, an idealized direct repeat RA-specific response element with 5-bp spacer (Umesono et al. 1991), was used as the probe, a binding complex was detected in the absence of ATRA in both cancer cell lines (Fig. 4B). After the nuclear protein was separately incubated with anti-RXR $\alpha$ or anti-RAR $\alpha$ antibody (represented in Fig. 4B with aRXR $\alpha$ or aRAR $\alpha$ respectively), the formation of the binding complex was significantly repressed in each case (Fig. 4B). This indicates that the complex was mainly composed of RAR $\alpha$ and RXR $\alpha$ protein. However, we noted that the binding complex formation could 
A.

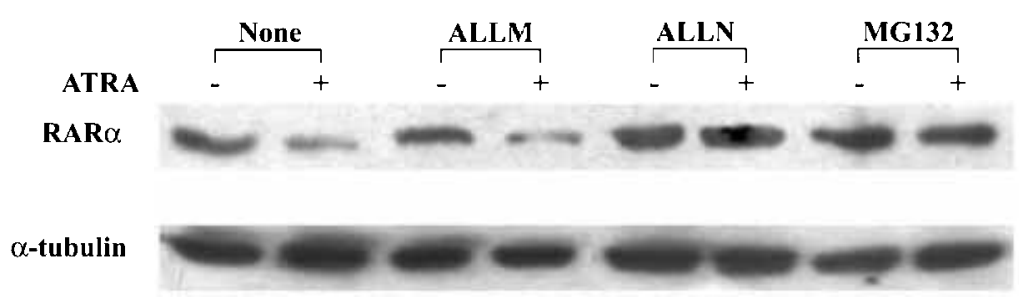

B.

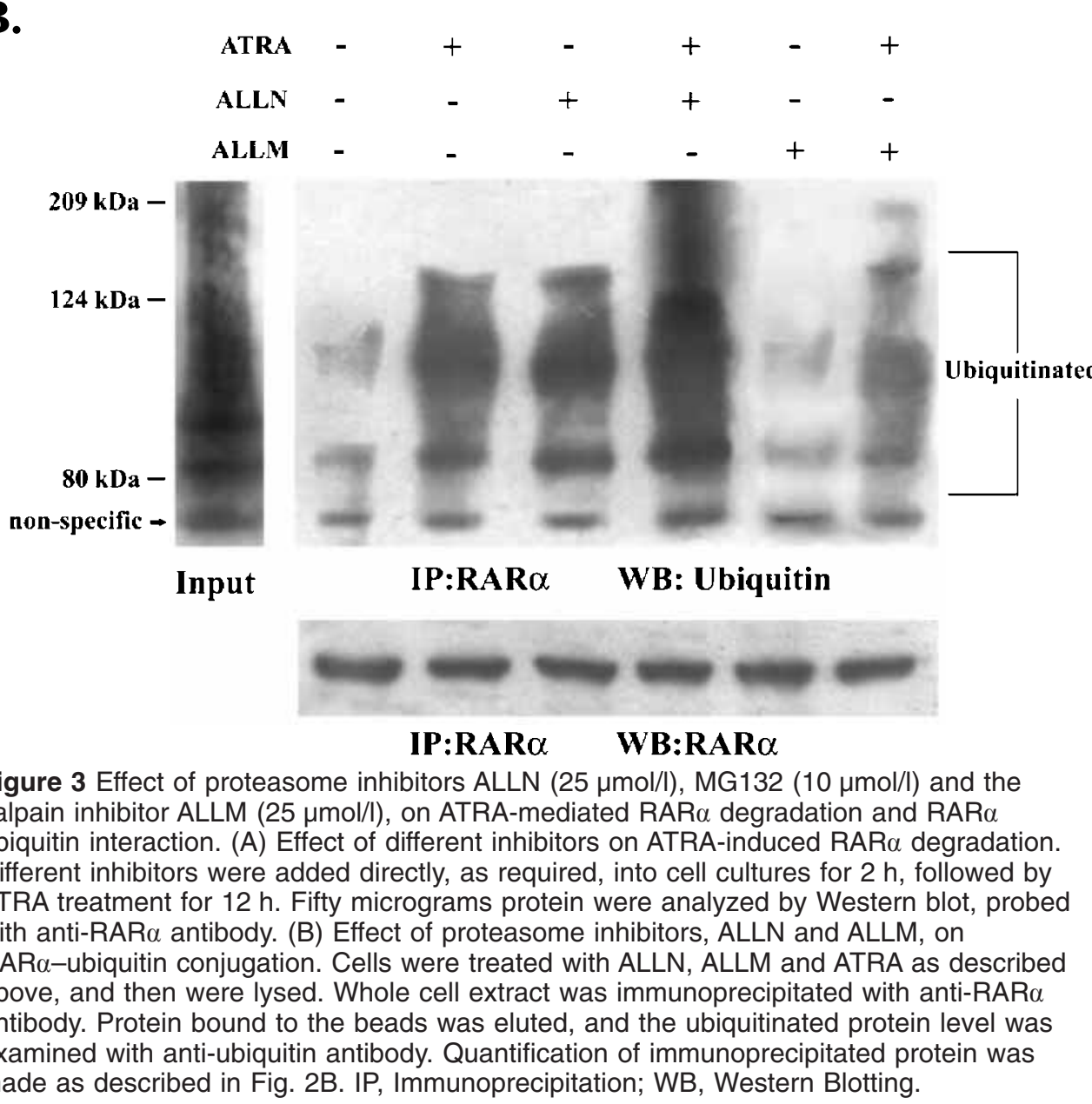




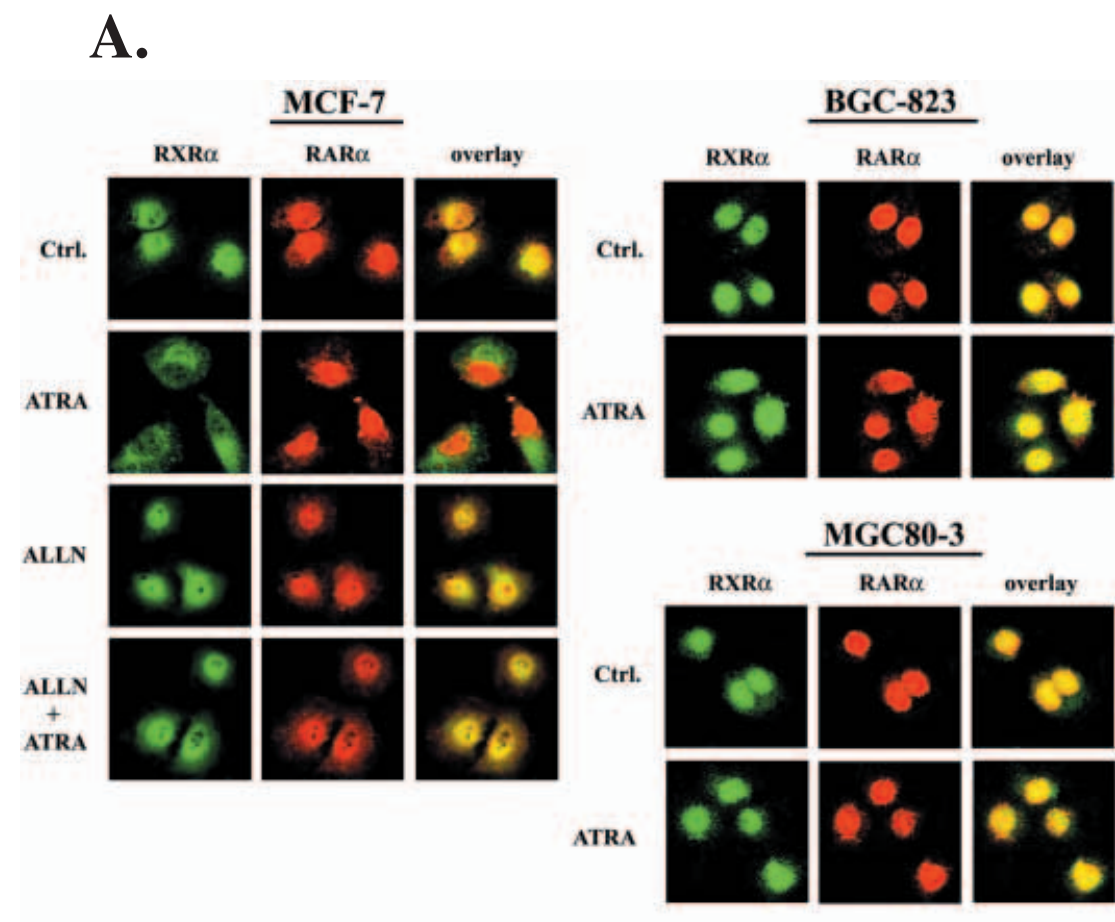

B.

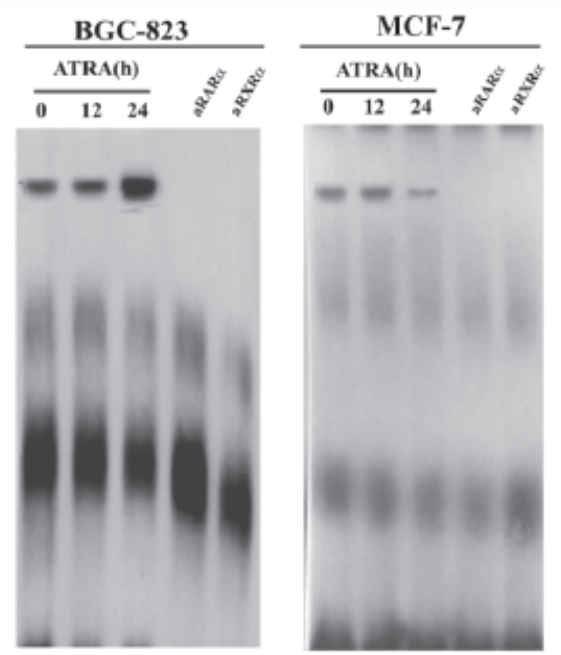

Figure $4(A)$ and (B).

be augmented in BGC-823 cells and decreased in MCF-7 cells under ATRA treatment of not less than $24 \mathrm{~h}$ (Fig. 4B). Immunoprecipitation/Western blot analysis further supported the view that endogenous RAR $\alpha$ was presented in a complex with RXR $\alpha$ in both MCF-7 and BGC-823 cells. The presence of this complex was clearly increased in BGC-823 cells and decreased in MCF-7 cells by $24 \mathrm{~h}$ of ATRA treatment (Fig. 4C). Good agreement in each panel of Fig. 4B and $\mathrm{G}$ supports the view that the $\mathrm{RAR} \alpha / \mathrm{RXR} \alpha$ heterodimer would be disassociated in MCF-7 cells and associated in BGC-823 cells in response to ATRA. 
C.

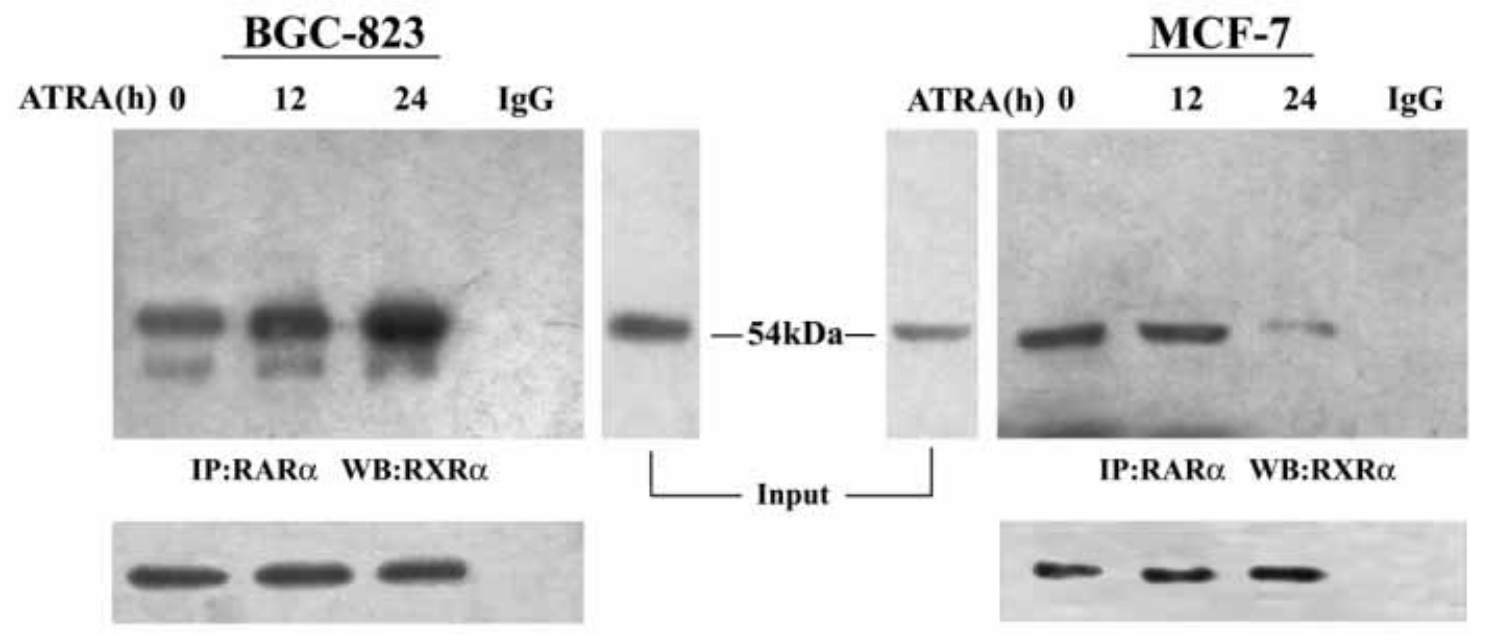

IP:RAR $\alpha$ WB:RAR $\alpha$

IP:RAR $\alpha$ WB:RAR $\alpha$

D.

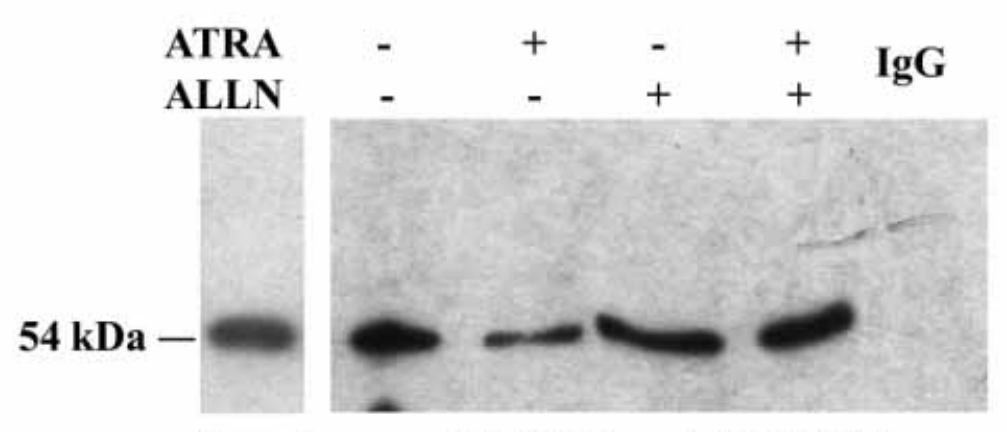

Input IP:RAR $\alpha$ WB:RXR $\alpha$

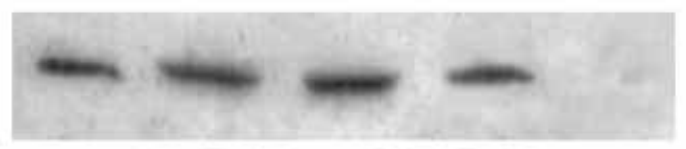

IP:RAR $\alpha \quad$ WB: RAR $\alpha$

Figure $4(C)$ and (D).

With the disassociation of RAR $\alpha$ and RXR $\alpha$ in ATRA-treated MCF-7 cells in mind, we supposed that the ubiquitination and degradation of RAR $\alpha$ may be the main cause for this disassociation. To investigate this by immunoprecipitation/Western blot analysis, ALLN was used to treat MCF-7 cells. The intensity of the RAR $\alpha / \mathrm{RXR} \alpha$ complex was not affected by ATRA (Fig. 4D) due to inhibition of the ubiquitination (Fig. 3B) and degradation pathways (Fig. 3A) of RAR $\alpha$ by ALLN. Thus, 
ubiquitination and degradation of $\mathrm{RAR} \alpha$ were proved to be responsible for the disassociation of RAR $\alpha$ with $R X R \alpha$. In addition, the confocal microscopic observation that ALLN blocked the ATRA-induced RXR $\alpha$ translocation from the nucleus to the cytoplasm (Fig. 4A) also strongly supports the blockage of the RAR $\alpha$ degradation pathway preventing its separation from $\operatorname{RXR} \alpha$ in MCF-7 cells.

\section{Sumoylation increases the stability of RAR $\alpha$ and facilitates heterodimerization of RAR $\alpha$ with RXRa}

The stability of sumoylated RAR $\alpha$ was then investigated. We measured the half-life of endogenous and sumoylated RAR $\alpha$ by pulse-chase experiment. In BGC-823 cells, the location of endogenous and sumoylated $\operatorname{RAR} \alpha$ was indicated by immunoprecipitation/Western blot (Fig. 5A, right and middle panels). Pulse-chase analysis revealed two major bands in the gel, corresponding to the endogenous RAR $\alpha$ and sumoylated RAR $\alpha$ respectively (Fig. 5A, left panel). In the absence of ATRA, the half-life of the endogenous $\operatorname{RAR} \alpha$ was less than $2 \mathrm{~h}$ and between 2 and $4 \mathrm{~h}$ for sumoylated RAR $\alpha$ (Fig. 5A, left panel and 5B, open bars), indicating that conjugation to SUMO-1 may stabilize RAR $\alpha$. Moreover, the half-life of sumoylated RAR $\alpha$ is clearly extended (after $6 \mathrm{~h}$ ) in the presence of ATRA (Fig. 5A, left panel and 5B, solid bars), demonstrating that ATRA could further stabilize sumoylated RAR $\alpha$. In addition, the relative level of $\operatorname{RAR} \alpha$ protein synthesized was higher in ATRA-treated (Fig. 5B solid bars) than in untreated BGC-823 cells (Fig. 5B open bars).
Taking Fig. 1D and Fig. 2C into account, it becomes clear that ATRA may accelarate the biosynthesis rate, increase the cellular content of RAR $\alpha$ protein and prolong its half-life via the sumoylation pathway.

The effects of ATRA on the behavioral aspects of RAR $\alpha$ as described above, were further examined by the same experimental approaches in another gastric cancer cell line MGC80-3. The results from MGC80-3 cells confirmed that ATRA can up-regulate RAR $\alpha$ protein synthesis (Fig. 5C), promote its sumoylation (Fig. 5D, right panel) and its heterodimerization with RXR $\alpha$ (Fig. 5D, left panel). The results also demonstrated that the nuclear location of both RAR $\alpha$ and RXR $\alpha$ was stable regardless of the presence or absence of ATRA (Fig. 4A) (refer to legend of relevant Figure for details). Clearly, these data are consistent with the experiments in the BGC-823 cell line and are further confirmation that in these gastric cancer cell lines, sumoylation of RAR $\alpha$ facilitates the formation of the RAR $\alpha / R X R \alpha$ heterodimer and restricts it to its original nuclear location. Thus, sumolaytion is advantageous for the $\mathrm{RAR} \alpha / \mathrm{RXR} \alpha$ heterodimer binding to its response element in signal transduction.

\section{Discussion}

In the present study, we have demonstrated that RAR $\alpha$ is covalently modified by both SUMO-1 and ubiquitin simultaneously in breast and gastric cancer cells. Interestingly, ATRA has directly the opposite effect on the sumoylation and ubiquitination of RAR $\alpha$ in cells of different cancer type, i.e. enhancing $\operatorname{RAR} \alpha$ sumoylation in gastric cancer

Figure 4 RAR $\alpha / R X R \alpha$ heterodimer is decreased by ubiquitination/degradation of RAR $\alpha$. (A) Effect of ALLN (pre-treatment for $2 \mathrm{~h}$ ) and ATRA (treatment for $24 \mathrm{~h}$ ) on translocation of RXR $\alpha$ and RAR $\alpha$ in different cancer cell lines. Cells were treated with different agents as indicated, and then immunostained with anti-RXR $\alpha$ or anti-RAR $\alpha$ antibody followed by the corresponding FITC-conjugated (for RXR $\alpha$ ) or Texas-red-conjugated (for RAR $\alpha$ ) secondary antibody to show the location of RXR $\alpha$ and RAR $\alpha$ protein respectively. The fluorescent images were visualized under a laser-scanning confocal microscope. (B) RAR $\alpha / R X R \alpha$ heterodimerization in both MCF-7 and BGC-823 cells. Heterodimerization of RAR $\alpha$ with RXR $\alpha$ was analyzed by gel retardation assay using ${ }^{32} \mathrm{P}$-labeled DR5 as a probe. To determine the formation of heterodimer, antibodies specific for RAR $\alpha$ and RXR $\alpha$ (designated as aRAR $\alpha$ and aRXR $\alpha$ ) were separately incubated with nuclear protein for $30 \mathrm{~min}$ at room temperature prior to the gel retardation assay. (C) Effect of ATRA on association of RAR $\alpha$ with RXR $\alpha$. Cell extract was immunoprecipitated with anti-RAR $\alpha$ antibody and subjected to SDS-PAGE, blotting and was then probed with anti-RXR $\alpha$ antibody. No band appeared at the position corresponding to RXR $\alpha$ in the negative control where IgG was used. (D) The effect of ALLN on RAR $\alpha / R X R \alpha$ complex formation in the presence of ATRA in breast cancer MCF-7 cells, analyzed by immunoprecipitation/Western blotting. No specific band for IgG could be seen. The immunoprecipitated RAR $\alpha$ used in each lane was quantified as described in Fig 2B. IP, Immunoprecipitation; WB, Western Blotting. 


\section{A.}

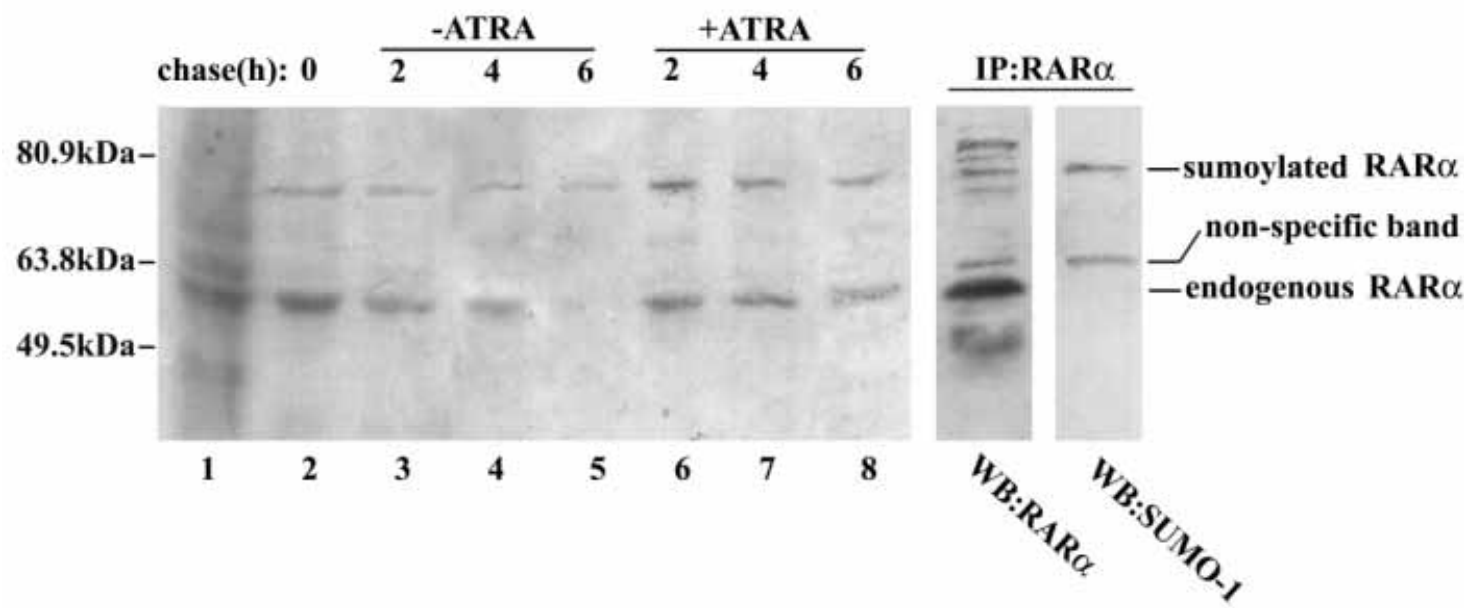

B.

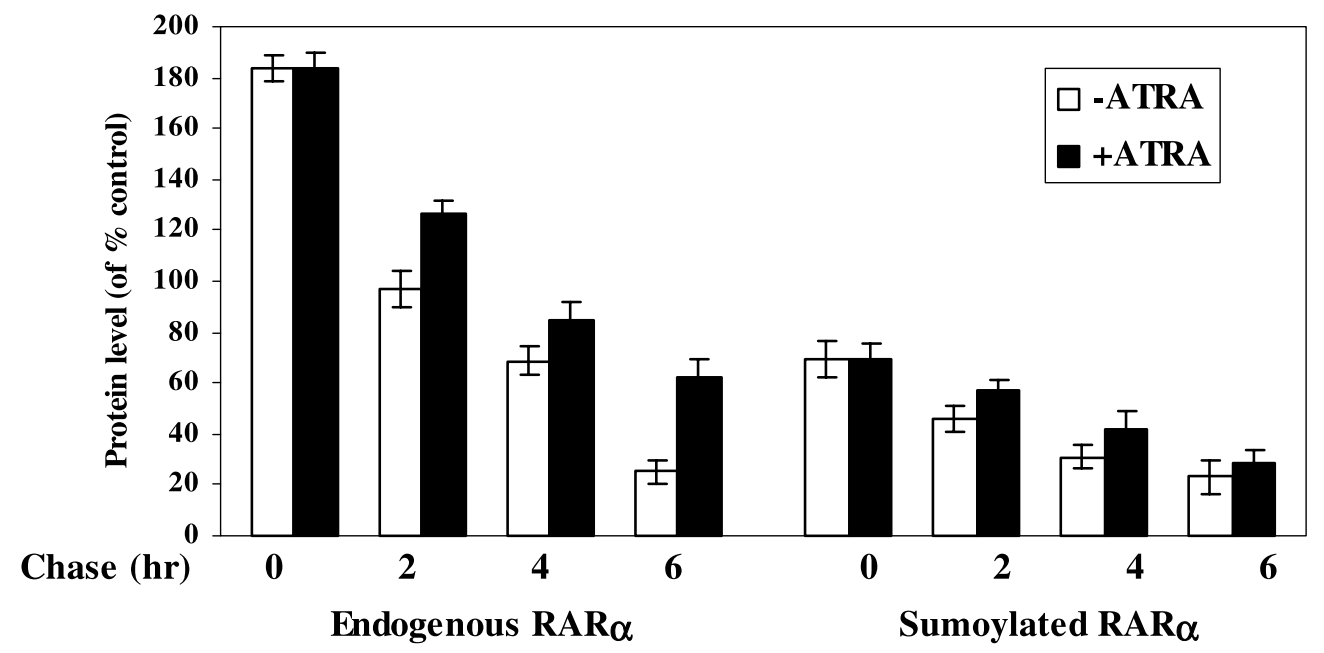

Figure $5(A)$ and $(B)$.

cells BGC-823 while restricting ubiquitination in breast cancer cells MCF-7. These regulatory effects of ATRA might be dependent on the distinct nature of cells from different tissue origins. Our findings may provide insight into a novel mechanism of ATRA on RAR $\alpha$ regulation through the dynamic balance between sumoylation and ubiquitination.
The ubiquitin/proteasome pathway is the major system in eukaryotic cells for the selective degradation of short-lived regulatory proteins and transcription factors (Haas \& Siepmann 1997, Pickart 1997). Covalent attachment of polyubiquitin is required for the efficient degradation of protein by the 26S proteasome complex (Hershko \& Ciechanover 1998). In breast cancer MCF-7 
C.
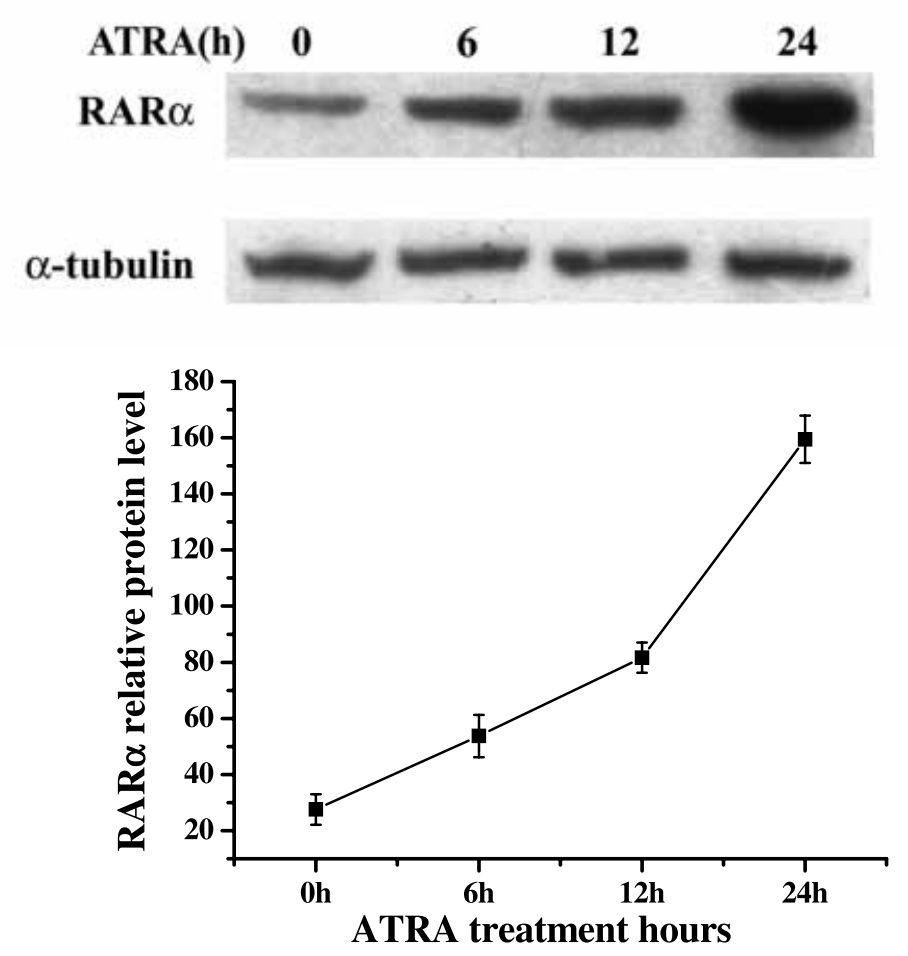

D.

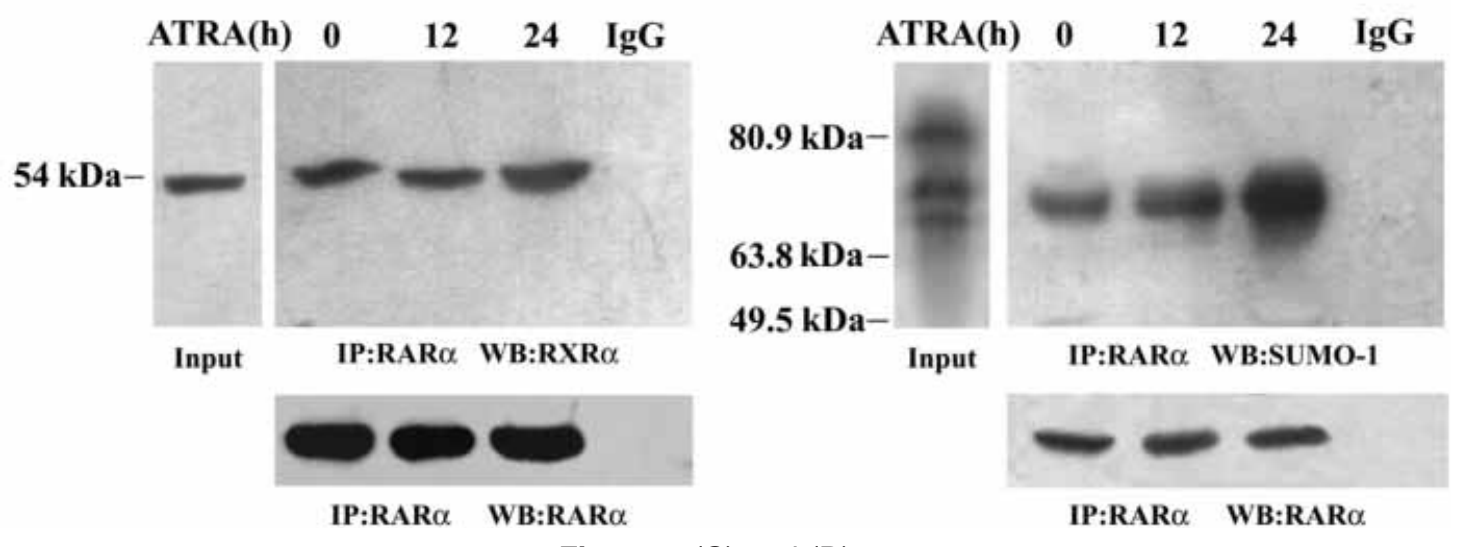

Figure $5(C)$ and (D).

cells, the inhibitory effect of ATRA on RAR $\alpha$ protein expression (Fig. 1A and B) could be blocked by proteasome-specific inhibitors (Fig. 3A), also indicating the involvement of the proteasome. In addition, polyubiquitin conjugating to RAR $\alpha$ promoted ATRA-induced RAR $\alpha$ ubiquitination in 
a time-dependent manner (Fig. 2B), whereas proteasome inhibition led to enhanced accumulation of polyubiquitin conjugates of RAR $\alpha$ even in the presence of ATRA (Fig. 3B). These results demonstrate that RAR $\alpha$ is specifically subjected to ubiquitination in an ATRA-regulated manner. It has been verified that a sequence known as PEST serves as a signal for proteolytic degradation (Rechsteiner \& Rogers 1996). RAR $\alpha$ contains a putative PEST sequence EEIVPSSPSPPPLPR (Swiss prot., No. P10276, Rogers et al. 1986), which is rich in Pro and Ser residues. Thus, the RAR $\alpha$ molecule meets this biological requirement for its degradation.

Consistent with our finding, the degradation of RARs through the ubiquitin/proteasome pathway has also been reported by other authors in other cell systems (Zhu et al. 1999, Boudjelal et al. 2000, Tanaka et al. 2001). However, what is significant about our results is that once $\operatorname{RAR} \alpha$ has been degraded by ATRA in MCF-7 cells, it prevents the heterodimerization of $\operatorname{RAR} \alpha / \operatorname{RXR} \alpha$ and its binding to DNA (Fig. 4B). In addition, RXR $\alpha$ becomes disassociated from RAR $\alpha$ (Fig. 4C) and is translocated to the cytoplasm (Fig. 4A). It is well known that the RAR/RXR heterodimer is a functional unit that preferentially transduces the retinoic acid signal in vivo and in vitro (Zhang et al. 1992, Kastner et al. 1995, Clifford et al. 1996, Chiba et al. 1997a,b, Wu et al. 1997a).

Recently, a number of publications have shown that the binding of RAR/RXR heterodimers to receptor response elements not only leads to positive transactivation but also signals a rapid destruction of active retinoid receptors ( $\mathrm{Zhu}$ et al. 1999, Kopf et al. 2000, Osburn et al. 2001). For example, the RA-induced degradation of RAR $\alpha 1$ and RAR $\gamma 2$ in transfected COS- 1 cells depends strictly on its heterodimerization with $\mathrm{RXR} \alpha$ (Kopf et al. 2000). Binding of the RAR/RXR heterodimer to DNA might be a triggering event for eliciting degradation (Zhu et al. 1999). Obviously, this evidence does not correspond to our observations. We have demonstrated that in MCF-7 cells, RAR $\alpha$ is degraded through the ubiquitin/proteasome pathway within $12 \mathrm{~h}$ of ATRA treatment (Fig. 1A and Fig. 2B) and that at least $24 \mathrm{~h}$ of treatment is needed for ATRA to repress the binding activity of $\mathrm{RAR} \alpha / \mathrm{RXR} \alpha$ heterodimer to its response element (Fig. 4B). These data suggest that RAR $\alpha$ degradation by ATRA might be an early event, which consequently caused repression of the extended transactivation of $\mathrm{RAR} \alpha / \mathrm{RXR} \alpha-\mathrm{DNA}$ binding. We therefore propose that the ubiquitination of $\operatorname{RAR} \alpha$ and the subsequent degradation by the proteasome might function by terminating the transcriptional activity of RAR $\alpha$ and RXR $\alpha$.

The result of the transient transfection assay in MCF-7 cells (Fig. 1C) further verifies that RAR $\alpha$ is not the main retinoic acid receptor engaged in transcriptional activity affected by ATRA in breast cancer cells. Thus, ubiquitination of $\operatorname{RAR} \alpha$ serves as a process for degradation and inactivation of the receptor in breast cancer cells. In this situation, RXR $\alpha$ becomes isolated from the RAR $\alpha / R X R \alpha$ heterodimer and translocates from the nucleus to the cytoplasm after $24 \mathrm{~h}$ of ATRA treatment. Accordingly, the augmented $\operatorname{RAR} \alpha$ ubiquitination and the disassociation of RAR $\alpha$ from $\operatorname{RXR} \alpha$ are likely to explain why our previous research shows that RAR $\alpha$ is incapable of exerting its function to mediate ATRA signals in MCF-7 cells (Ye et al. 2004). Certainly, further studies are necessary to establish if and how these differences may reflect

Figure 5 Sumoylation increases the stability of RAR $\alpha$ and facilitates RAR $\alpha / R X R \alpha$ heterodimerization. (A) Half-life of endogenous and sumoylated RAR $\alpha$ in BGC-823 cells. Cells were divided into two groups: cells in the first group were pulsed with ${ }^{35} \mathrm{~S}$-methionine for $4 \mathrm{~h}$ and chased in the absence or presence of ATRA for different times as indicated; cells in the remaining group were harvested for immunoprecipitation analysis. Protein samples, prepared as described in Materials and methods, were loaded onto 8\% SDS-PAGE gel simultaneously. The sample-loaded gel was cut into two parts: isotope-labeled gel was dried and exposed at $-80^{\circ} \mathrm{C}$ for 5 days (left panel, from lane 1 to 8 ); non-isotope-labeled gel was transferred to a nitrocellulose membrane, then subjected to Western blotting with corresponding antibodies as indicated (right and middle panels). As a control, lane 1 indicated total cell lysate. (B) Endogenous and sumoylated RAR $\alpha$ in a pulse-chase experiment were quantified by Densitometer. Data were means \pm S.D. of three independent experimental results. (C) Gastric cancer MGC80-3 cells were treated with ATRA for the indicated times. Expression of RAR $\alpha$ was examined by Western blot and quantified by Densitometer. (D) Effect of ATRA on interaction of RAR $\alpha$ with RXR $\alpha$ (left panel) or with SUMO-1 (right panel) in MGC80-3 cells, revealed by immunoprecipitation/Western blot. The duration of ATRA treatment is indicated. IP, Immunoprecipitation; WB, Western Blotting. 
specific functions of $\mathrm{RAR} \alpha$ in retinoic acid signaling under physiological conditions.

In addition to ubiquitination, an increasing number of cellular proteins have been found to covalently conjugate with SUMO-1 in eukaryotic cells. Although the molecular modification pathway of sumoylation resembles that of ubiquitination, their resultant functional consequences are different (Muller et al. 2001, Seeler \& Dejean 2001, Wilson \& Rangasamy 2001). In some cases, SUMO-1 antagonizes ubiquitin by conjugating onto the same lysine residue of target substrates, resulting in the stabilization of sumoylated proteins (Desterro et al. 1998, Hochstrasser 2000). A well-known example is the SUMO-1 modification of Mdm2 which prevents self-ubiquitination and increases Mdm2's ability to ubiquitinize p53 (Buschmann et al. 2000). In the present study, we demonstrated that both ubiquitinated and sumoylated RAR $\alpha$ are endogenously present in breast and gastric cancer cells (Fig. 2B and C). A typical consensus sequence of a protein sumoylation site is RVITLKMEIPGSM (Swiss prot., No. P10276, Johnson \& Blobel 1999, Sternsdorf et al. 1999a). The specific Lys residue found in $\mathrm{RAR} \alpha$ molecule, provides the possibility of $\operatorname{RAR} \alpha$ sumoylation.

In the present study, RAR $\alpha$ sumoylation was enhanced by ATRA in a time-dependent manner in BGC-823 cells (Fig. 2C), although ubiquitination of RAR $\alpha$ was still detectable (Fig. 2B). This suggests a possible dynastic balance mechanism between sumoylation and ubiquitination. When ATRA induced additional RAR $\alpha$ sumoylation in BGC823 cells, the RAR $\alpha$ molecule became stabilized and its half-life increased by at least $2 \mathrm{~h}$ (Fig. 5A and $\mathrm{B}$ ). This indicates that protein sumoylation may result in multiple biological outcomes, varying with the nature of the protein sumoylated. Sumoylation of the RAR $\alpha$ promoted binding of the $\mathrm{RAR} \alpha / \mathrm{RXR} \alpha$ heterodimer to the receptor response element (Fig. 4B) and enhanced its transcriptional activity (Fig. 1C). In addition to enhancing the transcriptional activity of the transfected reporter by cotransfection of RAR $\alpha$ in BGG-823 cells, the results also indicate the involvement of RAR $\alpha$ in ATRA signal transduction in relation to transcriptional activity in gastric cancer cells. Such a correlation between protein stability and transcriptional activity is in accordance with other reports (Kim \& Maniatis 1996, Molinari et al. 1999, Salghetti et al. 2000). When considered together, our observations confirm that SUMO-1 conjugation could stabilize RAR $\alpha$, keep the $\mathrm{RAR} \alpha / \mathrm{RXR} \alpha$ heterodimer fixed in the nucleus, as well as stimulate the binding of RAR $\alpha /$ RXRa to DNA, promoting its transcriptional activity. Thus SUMO-1 conjugation is a critical step of functional significance in the pathway of ATRA signal transduction.

In summary, RAR $\alpha$ may be subjected to either ubiquitination or sumoylation. In breast cancer MCF-7 cells, degradation of RAR $\alpha$ by ATRA is through the ubiquitin/proteasome pathway, which consequently leads to inhibition of the RAR $\alpha$ / RXR $\alpha$ heterodimer binding to DNA. Under these circumstances, $\mathrm{RXR} \alpha$ disassociates with $\mathrm{RAR} \alpha$, and then translocates from the nucleus to the cytoplasm. By contrast, in gastric cancer BGC-823 cells ATRA-induced up-regulation of RAR $\alpha$ is closely associated with its sumoylation. ATRAenhanced RAR $\alpha$ sumoylation promotes the stability of RAR $\alpha$ and the steady nuclear localization of $\mathrm{RAR} \alpha / \mathrm{RXR} \alpha$, which is then capable of serving as a functional unit in ATRA signal transduction. These results reveal a novel mechanism: in its sumoylated form, RAR $\alpha$ is more efficient in mediating ATRA signals than ubiquitinated RAR $\alpha$.

\section{Acknowledgements}

This work was supported by the National Natural Science Foundation of China (No. 30170477), the National Outstanding Youth Science Foundation of China (No. 39825502), and the National Natural Science Foundation of Fujian Province (C0110004). We thank Dr Xiao-kun Zhang (Burnham Institute, La Jolla, CA, USA) for the kind gifts of $\operatorname{RAR} \alpha$ and $\operatorname{RXR} \alpha$ probes.

\section{References}

Boudjelal M, Wang Z, Voorhees JJ \& Fisher GJ 2000 Ubiquitin/ proteasome pathway regulates levels of retinoic acid receptor gamma and retinoid $\mathrm{X}$ receptor alpha in human keratinocytes. Cancer Research 60 2247-2252.

Bugge TH, Pohl J, Lonnoy O \& Stunnenberg HG 1992 RXR alpha, a promiscuous partner of retinoic acid and thyroid hormone receptors. EMBO fournal 11 1409-1418.

Buschmann T, Fuchs SY, Lee CG, Pan ZQ \& Ronai Z 2000 SUMO-1 modification of Mdm2 prevents its self-ubiquitination and increases $\mathrm{Mdm} 2$ ability to ubiquitinate p53. Cell $\mathbf{1 0 1}$ $753-762$. 
Chiba H, Clifford J, Metzger D \& Chambon P $1997 a$ Distinct retinoid $\mathrm{X}$ receptor-retinoic acid receptor heterodimers are differentially involved in the control of expression of retinoid target genes in F9 embryonal carcinoma cells. Molecular and Cellular Biology 17 3013-3020.

Chiba H, Clifford J, Metzger D \& Chambon P $1997 b$ Specific and redundant functions of retinoid $\mathrm{X}$ receptor/retinoic acid receptor heterodimers in differentiation, proliferation, and apoptosis of F9 embryonal carcinoma cells. Fournal of Cell Biology $139735-747$.

Clifford J, Chiba H, Sobieszczuk D, Metzger D \& Chambon P 1996 RXRalpha-null F9 embryonal carcinoma cells are resistant to the differentiation, anti-proliferative and apoptotic effects of retinoids. EMBO foumal 15 4142-4155.

Desterro JM, Rodriguez MS \& Hay RT 1998 SUMO-1 modification of IkappaBalpha inhibits NF-kappaB activation. Molecular Cell 2 233-239.

Duprez E, Saurin AJ, Desterro JM, Lallemand-Breitenbach V, Howe K, Boddy MN, Solomon E, de The H, Hay RT \& Freemont PS 1999 SUMO-1 modification of the acute promyelocytic leukaemia protein PML: implications for nuclear localisation. Fournal of Cell Science 112 381-393.

Fenteany G, Standaert RF, Lane WS, Choi S, Corey EJ \& Schreiber SL 1995 Inhibition of proteasome activities and subunit-specific amino-terminal threonine modification by lactacystin. Science 268 726-731.

Gianni M, Bauer A, Garattini E, Chambon P \& Rochette-Egly C 2002 Phosphorylation by p38 MAPK and recruitment of SUG-1 are required for RA-induced RAR gamma degradation and transactivation. EMBO Journal 21 3760-3769.

Goldstein G, Scheid M, Hammerling U, Schlesinger DH, Niall HD \& Boyse EA 1975 Isolation of a polypeptide that has lymphocyte-differentiating properties and is probably represented universally in living cells. PNAS $7211-15$.

Gostissa M, Hengstermann A, Fogal V, Sandy P, Schwarz SE, Scheffner M \& Del Sal G 1999 Activation of p53 by conjugation to the ubiquitin-like protein SUMO-1. EMBO Fournal 18 6462-6471.

Gudas LJ, Sporn MB \& Roberts AB 1994 Cellular biology and biochemistry of the retinoids. In The Retinoids, edn 2, pp 443-520. Eds MB Sporn, AB Roberts \& DS Goodman. New York: Raven Press.

Haas AL \& Siepmann TJ 1997 Pathways of ubiquitin conjugation. FASEB Fournal 11 1257-1268.

Hershko A \& Ciechanover A 1998 The ubiquitin system. Annual Review of Biochemistry 67 425-479.

Hochstrasser M 1996 Ubiquitin-dependent protein degradation. Annual Review of Genetics 30 405-439.

Hochstrasser M 2000 Evolution and function of ubiquitin-like protein-conjugation systems. Nature Cell Biology 2 E153-E157.

Hoffmann B, Lehmann JM, Zhang XK, Hermann T, Husmann M, Graupner G \& Pfahl M 1990 A retinoic acid receptor-specific element controls the retinoic acid receptor-beta promoter. Fournal of Molecular Endocrinology 4 1727-1736.

Hong WK \& Itri LM 1994 Retinoids and human cancer. In The Retinoids, edn 5, pp 597-630. Eds MB Sporn, AB Roberts \& DS Goodman. New York: Raven Press.

Johnson ES \& Blobel G 1999 Cell cycle-regulated attachment of the ubiquitin-related protein SUMO to the yeast septins. Fournal of Cell Biology 147 981-994.

Johnson ES, Schwienhorst I, Dohmen RJ \& Blobel G 1997 The ubiquitin-like protein Smt3p is activated for conjugation to other proteins by an Aoslp/Uba2p heterodimer. EMBO Fournal 16 $5509-5519$.

Kamitani T, Kito K, Nguyen HP \& Yeh ET 1997 Characterization of NEDD8, a developmentally down-regulated ubiquitin- like protein. Fournal of Biological Chemistry 272 28557-28562.
Kastner P, Mark M \& Chambon P 1995 Nonsteroid nuclear receptors: what are genetic studies telling us about their role in real life? Cell $\mathbf{8 3}$ 859-869.

Kim TK \& Maniatis T 1996 Regulation of interferon-gammaactivated STAT 1 by the ubiquitin-proteasome pathway. Science 273 1717-1719.

Kliewer SA, Umesono K, Mangelsdorf DJ \& Evans RM 1992 Retinoid X receptor interacts with nuclear receptors in retinoic acid, thyroid hormone and vitamin D3 signalling. Nature 355 446-449.

Kopf E, Plassat JL, Vivat V, de The H, Chambon P \& Rochette-Egly C 2000 Dimerization with retinoid X receptors and phosphorylation modulate the retinoic acid-induced degradation of retinoic acid receptors alpha and gamma through the ubiquitin-proteasome pathway. Fournal of Biological Chemistry 275 33280-33288.

Lallemand-Breitenbach V, Zhu J, Puvion F, Koken M, Honore N, Doubeikovsky A, Duprez E, Pandolfi PP, Puvion E, Freemont P \& de The H 2001 Role of promyelocytic leukemia (PML) sumolation in nuclear body formation, $11 \mathrm{~S}$ proteasome recruitment, and As2O3-induced PML or PML/retinoic acid receptor alpha degradation. Fournal of Experimental Medicine 193 1361-1371.

Lee DH \& Goldberg AL 1998 Proteasome inhibitors: valuable new tools for cell biologists. Trends in Cell Biology 8 397-403.

Leid M, Kastner P, Lyons R, Nakshatri H, Saunders M, Zacharewski T, Chen JY, Staub A, Garnier JM, Mader S \& Chambon D 1992 Purification, cloning, and RXR identity of the HeLa cell factor with which RAR or TR heterodimerizes to bind target sequences efficiently. Cell 68 377-395.

Li XY, Boudjelal M, Xiao JH, Peng ZH, Asuru A, Kang S, Fisher GJ \& Voorhees JJ 1999 1,25-Dihydroxyvitamin D3 increases nuclear vitamin D3 receptors by blocking ubiquitin/ proteasome-mediated degradation in human skin. Molecular Endocrinology 13 1686-1694.

Mahajan R, Delphin C, Guan T, Gerace L \& Melchior F 1997 A small ubiquitin-related polypeptide involved in targeting RanGAP1 to nuclear pore complex protein RanBP2. Cell $\mathbf{8 8}$ 97-107.

Marks MS, Hallenbeck PL, Nagata T, Segars JH, Appella E, Nikodem VM \& Ozato K 1992 H-2 RIIBP (RXR beta) heterodimerization provides a mechanism for combinatorial diversity in the regulation of retinoic acid and thyroid hormone responsive genes. EMBO Journal 11 1419-1435.

Melchior F 2000 SUMO-nonclassical ubiquitin. Annual Review of Cell and Developmental Biology 16 591-626.

Molinari E, Gilman M \& Natesan S 1999 Proteasome-mediated degradation of transcriptional activators correlates with activation domain potency in vivo. EMBO Journal 18 6439-6447.

Muller S, Hoege C, Pyrowolakis G \& Jentsch S 2001 SUMO, ubiquitin's mysterious cousin. Nature Revieres Molecular Cell Biology 2 202-210.

Nawaz Z, Lonard DM, Dennis AP, Smith CL \& O'Malley BW 1999 Proteasome-dependent degradation of the human estrogen receptor. PNAS 96 1858-1862.

Osburn DL, Shao G, Seidel HM \& Schulman IG 2001 Liganddependent degradation of retinoid $\mathrm{X}$ receptors does not require transcriptional activity or coactivator interactions. Molecular and Cellular Biology 21 4909-4918.

Pickart CM 1997 Targeting of substrates to the 26S proteasome. FASEB Fournal 11 1055-1066.

Rechsteiner M \& Rogers SW 1996 PEST sequences and regulation by proteolysis. Trends in Biochemical Sciences 21 267-271.

Rock KL, Gramm C, Rothstein L, Clark K, Stein R, Dick L, Hwang D \& Goldberg AL 1994 Inhibitors of the proteasome block the degradation of most cell proteins and the generation of peptides presented on MHC class I molecules. Cell 78 761-771. 
Rodriguez MS, Desterro JM, Lain S, Midgley CA, Lane DP \& Hay RT 1999 SUMO-1 modification activates the transcriptional response of p53. EMBO Fournal 18 6455-6461.

Rogers S, Wells R \& Rechsteiner M 1986 Amino acid sequences common to rapidly degraded proteins: the PEST hypothesis. Science 234 364-368.

Russell SJ, Reed SH, Huang W, Friedberg EC \& Johnston SA 1999 The 19S regulatory complex of the proteasome functions independently of proteolysis in nucleotide excision repair. Molecular Cell 3 687-695.

Salghetti SE, Muratani M, Wijnen H, Futcher B \& Tansey WP 2000 Functional overlap of sequences that activate transcription and signal ubiquitin-mediated proteolysis. PNAS 97 3118-3123.

Seeler JS \& Dejean A 2001 SUMO: of branched proteins and nuclear bodies. Oncogene 20 7243-7249.

Spence J, Gali RR, Dittmar G, Sherman F, Karin M \& Finley D 2000 Cell cycle-regulated modification of the ribosome by a variant multiubiquitin chain. Cell 102 67-76.

Sternsdorf T, Jensen K, Reich B \& Will H 1999a The nuclear dot protein sp100, characterization of domains necessary for dimerization, subcellular localization, and modification by small ubiquitin-like modifiers. Foumal of Biological Chemistry 274 12555-12566.

Sternsdorf T, Puccetti E, Jensen K, Hoelzer D, Will H, Ottmann OG \& Ruthardt M 1999b PIC-1/SUMO-1-modified PML-retinoic acid receptor alpha mediates arsenic trioxideinduced apoptosis in acute promyelocytic leukemia. Molecular and Cellular Biology 19 5170-5178.

Tanaka T, Rodriguez de la Concepcion ML \& De Luca LM 2001 Involvement of all-trans-retinoic acid in the breakdown of retinoic acid receptors alpha and gamma through proteasomes in MCF-7 human breast cancer cells. Biochemical Pharmacology 61 1347-1355.

Terrell J, Shih S, Dunn R \& Hicke L 1998 A function for monoubiquitination in the internalization of a $G$ protein-coupled receptor. Molecular Cell 1 193-202.

Thrower JS, Hoffman L, Rechsteiner M \& Pickart CM 2000 Recognition of the polyubiquitin proteolytic signal. EMBO fournal $1994-102$.

Umesono K, Murakami KK, Thompson CC \& Evans RM 1991 Direct repeats as selective response elements for the thyroid hormone, retinoic acid, and vitamin D3 receptors. Cell 65 $1255-1266$.

Weissman AM 1997 Regulating protein degradation by ubiquitination. Immunology Today 18 189-198.

Wilkinson KD 2000 Ubiquitination and deubiquitination: targeting of proteins for degradation by the proteasome. Seminars in Cell and Developmental Biology 11 141-148.
Wilson VG \& Rangasamy D 2001 Intracellular targeting of proteins by sumoylation. Experimental Cell Research 271 57-65.

Wu Q Dawson MI, Zheng Y, Hobbs PD, Agadir A, Jong L, Li Y, Liu R, Lin B \& Zhang XK $1997 a$ Inhibition of trans-retinoic acid-resistant human breast cancer cell growth by retinoid $\mathrm{X}$ receptor-selective retinoids. Molecular and Cellular Biology 17 6598-6608.

Wu Q, Li Y, Liu R, Agadir A, Lee MO, Liu Y \& Zhang X $1997 b$ Modulation of retinoic acid sensitivity in lung cancer cells through dynamic balance of orphan receptors nur77 and COUP-TF and their heterodimerization. EMBO Fournal 16 1656-1669.

Wu Q Chen ZM \& Su WJ $2002 a$ Anticancer effect of retinoic acid via AP-1 activity repression is mediated by retinoic acid receptor alpha and beta in gastric cancer cells. International Journal of Biochemistry and Cell Biology 34 1102-1114.

Wu Q Liu S, Ye XF, Huang ZW \& Su WJ $2002 b$ Dual roles of Nur77 in selective regulation of apoptosis and cell cycle by TPA and ATRA in gastric cancer cells. Carcinogenesis 23 1583-1592.

Wu Q, Zhang M, Liu S, Chen Y \& Su W 2002c Retinoic acid receptor beta is required for anti-activator protein-1 activity by retinoic acid in gastric cancer cells. Chinese Medical fournal 115 810-814 (in English).

Ye XF, Wu Q, Liu S, Lin XF, Zhang B, Wu JF, Cai JH, Zhang MQ \& Su WJ 2004 Distinct role and functional mode of TR3 and RAR $\alpha$ in mediating TRA-induced signaling pathway in breast and gastric cancer cells. International Fournal of Biochemistry and Cell Biology 36 98-113.

Yu VC, Delsert C, Andersen B, Holloway JM, Devary OV, Naar AM, Kim SY, Boutin JM, Glass CK \& Rosenfeld MG 1991 RXR beta: a coregulator that enhances binding of retinoic acid, thyroid hormone, and vitamin $\mathrm{D}$ receptors to their cognate response elements. Cell 67 1251-1266.

Zhang XK \& Pfahl M 1993 Hetero- and homodimeric receptors in thyroid hormone and vitamin A action. Receptor 3 183-191.

Zhang XK, Hoffmann B, Tran PB, Graupner G \& Pfahl M 1992 Retinoid X receptor is an auxiliary protein for thyroid hormone and retinoic acid receptors. Nature 355 441-446.

Zhu J, Gianni M, Kopf E, Honore N, Chelbi-Alix M, Koken M, Quignon F, Rochette-Egly C \& de The H 1999 Retinoic acid induces proteasome-dependent degradation of retinoic acid receptor alpha (RARalpha) and oncogenic RARalpha fusion proteins. PNAS 96 14807-14812.

Received in final form 9 January 2004

Accepted 3 February 2004

Made available online as an Accepted Preprint 